\title{
An Acoustic Measurements of English Stops Produced by Native Yemeni Arabic Speakers of English (NYASE)
}

\author{
Ramzi Abdullah Mansour Naji \\ Faculty of Indian Languages, Annamalai University, India \\ $\underline{\text { ramzi77abdullah.qaid@gmail.com }}$
}

$\begin{array}{ll}\text { Received: } & \text { Abstract } \\ \text { 25/08/2019 } & \text { Acoustically, this paper investigates English stops consonants as produced } \\ \text { Accepted: } & \text { by NYASE. The researcher examines the voicing of six stops by the use of } \\ \text { Voice Onset Time (henceforth VOT) method. This inquiry aims to identify } & \text { how similar/different the VOT patterns produced by NYASE to the VOT- } \\ & \text { literature-based patterns produced by native speakers of English. The } \\ \text { Subjects of this study are two Yemeni adults doing their Ph.D. at } & \text { Annamalai University, Center of Advanced Study in Linguistics. They were } \\ \text { Acoustic } & \text { chosen based on a self-evaluation test. Those subjects who evaluated } \\ \text { Measurements, } & \text { themselves as having an 'excellent' command over English were selected } \\ \text { Voice Onset Time, } & \text { to participate in this study. Knowingly, the subjects are late bilinguals, who } \\ \text { English Stops, Native } & \text { learned English in their adulthood. Later on, the targeted sounds in word- } \\ \text { Yemeni Arabic } & \text { initial position, pre-vocalically, in monosyllabic words, and in their } \\ \text { Speakers of English. } & \text { citation form, have been recorded and analyzed following Lisker and } \\ & \text { Abramson (1964) procedures. Wide-band spectrograms cross-checked with } \\ \text { waveforms were made, and from them, VOT was measured by 'marking off } \\ \text { the interval between the release of the stop and the onset of voicing'. The } \\ \text { acoustic measurements showed that NYASE produce long lag VOT } \\ \text { patterns for voiceless stop, long lead VOT patterns for voiced ones. }\end{array}$

\section{INTRODUCTION}

In describing human speech sounds in general, phoneticians frequently depend on the place of articulation, manner of articulation and voicing. Based on voicing distinction, they classify sounds into voiced and voiceless. The voiced categories are characterized by the presence of glottal buzz during the interval of articulatory closure, while the absence of the glottal buzz during the interval of articulatory closure is a marker of voiceless ones (Lisker and Abramson: 1964:527). Acoustically, they are distinguished by the absence or presence of a small number of low-harmonic components in the formantless segment corresponding to their closure interval in their spectrographic patterns (Ibid). The presence of low-harmonic components entails voiced categories, while their absence characterizes voiceless stops. Besides voicing, phoneticians sometimes invoke some other dimensions like aspiration and force of articulation (fortis/lenis) to separate homorganic stop categories. These three dimensions, in addition to many other acoustic cues (e.g., burst intensity, spectral shape, and formant frequencies of the following vowel) work either in tandem or independently. However, various points of views on whether these three distinctive features work on the individual level or with other features were held. Based on the literature available, none of these categories can stand by itself to separate homorganic stop categories (e.g., /p, t, k/ from /b, d, g/, at least in 
English, in all environments, in which these contrasting stops can occur. The dimension of voicing works in part for English stop categories (Lisker and Abramson: 1964, 528). For instance, the /b, d, g/ of English show a silent interval closure in their spectrographic patterns, which means they are physically voiceless. 'Phoneticians rarely call those sounds voiceless'. They look for another phonetic dimension namely; an aspiration to distinguish between these categories in an initial position and medially before a stressed syllable, but in many non-final positions /b, d, g/ are unlike /p, t, k/. They are not released with an audible explosion and an interlude of noise. Another phonetic dimension, a force of articulation (fortis/lenis), is brought along with the first two dimensions to fill the gap. But Lisker and Abramson (1946: 530) emphasize that "none of the acoustic features which have been suggested as correlates of a fortis/lenis dimension demonstrably independent of voicing'.

The two authors are in support of Gunnar Fant's Acoustic Theory of Speech Production, in which he emphasized the needlessness for positing independent fortis/lenis differences. Kim (1965) refuted Lisker and Abramson's argument and provided some evidence with special reference to Korean stops. He stated that these terms have phonetic meanings, that the tense/ lax distinction is an autonomous feature; that they have articulatory and acoustic correlates, and that they are physiologically definable. Kim claimed that 'it is necessary to recognize categories, tensity and voicing for the precise description of stops...' He also held that neither tensity, nor voicing is a universally primary feature over the other, but they are language dependent features. For distinguishing stops' manner of articulation, Lisker and Abramson, in their cross-language study of the voicing of stops in word-initial position, aimed at finding the acoustic characteristic which functions as a single cue for separating stops from each other by paying attention to the timing relation between voice onset timing and the release of the occlusion. They coined the term VOT, as the best single basis for the physical discrimination of stops manner categories.

Since the earlier time of the prevalence of the term VOT, a great number of works investigating voicing by the use of the VOT method have been conducted. A large portion of these studies has seemingly been in English language while other considerable works have been done in different languages (e.g., in Arabic: Rifaat, 2003; Tamim, 2017; Al-Ani, 1970; Al-Nuzaili, 1993; Al-Masri Mohammed and Jongman, 2004; Khattab, Al-Tamimi, and Heselwood, 2006; Al-Dahri, 2013; in Chinese and English: Cho \& Chen, 2008, and in English: Lisker \& Abramson, 1964, 1967; Lisker, 1970, 1977; and Abramson, 1995). VOT has been employed to study a variety of speech either considering a society (e.g., how differences in VOT correlate with sociological categories) and/or independently of it. It was also employed to execute an inquiry about language disorders such as dysarthrias (e.g., Lehiste, 1965; Campbell \& Dollaghan, 1995) and stuttering (e.g., Angello, Wingate, and Wendell, 1974; Di Simoni, 1974; Farmer \& Brayton, 1979; Viswanath \& Neel, 1995). Many other previous studies have focused on testing VOT value in the speech of bilingual adults (e.g., Sundara et al., 2006) and children (e.g.,Khattab, 2000).

To the best of my knowledge, there is no work dedicated to carrying out a study about English Stops as produced by NYASE. Therefore, this study aimed at filling this gap and finding to what extent NYASE could learn from the fine-grained phonetic details. It is also intended to see if the VOT stands as a sufficient acoustic correlate of the stop voicing and its 
efficiency in separating English stop consonants as produced by NYASE. The main questions addressed here are: what are the VOT patterns produced by NYASE? How similar/different they are from that patterns produced by native English speakers reported in the literature? Furthermore, this paper examines whether tokens recorded in different sessions vary in terms of their VOT or not. It is hypothesized that NYASE will produce the same VOT patterns as that of their mother tongue.

\subsection{Definition of VOT}

It is a duration measurement, which captures the timing relation between the oral stop release and the onset of the vocal fold pulsing. According to Lisker and Abramson (1964: 422), VOT is 'the time interval between the burst that marks the release of the stop closure and the onset of quasi-periodicity which reflects laryngeal vibration'. Cho \& Ladefoged (1999: 225) defined VOT as 'the time between the initiation of the articulatory gesture responsible for the release of closure and the initiation of the laryngeal gesture responsible for vocal fold vibration'. VOT is usually measured in milliseconds, visualized with waveforms, and measured in a wideband spectrogram. In most cases, authors determine VOT by locating the first of the regularly spaced vertical striations, which marks the glottal pulsing, while the instant release can be determined by fixing the point where pattern shows an abrupt change in overall spectrum. Klatt (1975) defined the end of positive VOT value by looking at the onset of striations in the second formant of the following vowel.

VOT was employed to measure the timing of voicing and to distinguish stop categories from one another. However, the latter employment has been brought into question. For example, Bohn and Fledge (1993) in their findings suggested that VOT may not be as important to the perception of stop voicing as is commonly supposed. Lisker and Abramson also proposed that there are three general realizations of pre-voiced stops in the world's languages. These can be defined by their VOT values as (1) zero to $+25 \mathrm{~ms}$ (voiceless and unaspirated stops), (2) +60 to $+100 \mathrm{~ms}$ (voiceless and aspirated stops), and (3) -125 to $-75 \mathrm{~ms}$ (voiced stops).

In (1); the voicing begins after the release; in (2), the voice onset lags considerably behind the release; and in (3) the onset of vibration occurs during the release of the closure, resulting in a negative VOT value. These categories are also defined in terms of lead and lag. The voicing lead represents the negative value and the voicing lag stands for the positive value. The voicing lag can either be long or short. Therefore, (1), (2), and (3) are short lag, long lag, and lead VOT consecutively. Similarly, Cho and Ladefoged (1999) concluded that the target VOT values are determined at a language-specific level within the three broad phonetic categories referred to above.

\section{REVIEW OF RELATED LITERATURE}

\subsection{Types of Languages According to VOT}

Languages are classified into two group languages in terms of VOT. Group $A$ languages have long VOT, over 50 milliseconds for a voiceless stop, but a short for voiced ones. On the other hand, group $B$ languages have a short VOT, less than 30 milliseconds, for voiceless stops, but a negative one for voiced stops. Classifying languages according to whether they belong to group $A$ or $B$ is controversial. For instance, Al-Ani (1970) and Mitleb (2009) showed that Arabic is a member of group A while Yeni-Komshian et. al. (1977) showed that Arabic is a 
member of group B. Some other researchers like Flege (1979) held that Arabic belongs neither to A nor to B.

\subsection{Cross-language Studies of VOT}

In1964, Lisker and Abramson began their study aiming at finding how a single phonetic dimension serves to separate stop categories of languages in which both the number and phonetic characteristics of such categories are said to differ. Their study was limited to wordinitial position and before vowels. They expected that word-initial stop categories have differences in their VOT, which can separate stop categories from one another. However, they did not expect it to mark off the so-called voiced aspirated categories in Hindi and Marathi.

Table 1. 11 Languages Based on Their Stop Categories (Liskar \& Abramson, 1964)

\begin{tabular}{cccc}
\hline No. & Two Categories & Three categories. & Four categories \\
\hline 1 & American English & Korean & Hindi \\
\hline 2 & Cantonese & Eastern Armenian & Marathi \\
\hline 3 & Dutch & Thai & \\
\hline 4 & Puerto & & \\
\hline 5 & Rican Spanish & & \\
\hline 6 & Tamil & & \\
\hline
\end{tabular}

Both authors investigated the languages in table 1 above deeply, in word-initial position and before a vowel. They found that VOT and aspiration separate the stops into two, three, and four stops categories. Thus, Dutch, Spanish, Hungarian and Tamil occupy the ranges about -100 and $+10 \mathrm{msec}$. This means that they had their value in voicing lead and short voicing lag. Cantonese locates its stop categories in the +10 and $+75 \mathrm{msec}$; hence in the short and long voicing lag. English is the same as Cantonese having two opposition types, distributed in the short and long voicing lag, except for a scattering of items in the $-100 \mathrm{msec}$ range. But they occupied different ranges. Languages with three opposition types were Eastern Armenian and Thai. Their three categories were distributed over the ranges centering at $-100,+10$, and +75 msec. Korean, a three-category language is odd in that all its stop categories were distributed in the voicing lag. The mean value in msec, according to Kim (1965) is $+12,+35$, and +93 for voiceless unaspirated tense series /p, t, k/, voiceless slightly aspirated lax series /p, t, k/ and voiceless strongly aspirated tense series $/ \mathrm{p}^{\mathrm{h}}, \mathrm{t}^{\mathrm{h}}, \mathrm{k}^{\mathrm{h}}, /$ respectively. This distribution of Korean stops is in the voicing lag. According to Kim, the distribution is not satisfactory. Overlapping in the distribution of these stops was seen. Separating of stop categories in Korean seems problematic and linguists held different points of views about the way of separating them. While Lisker \& Abramson did not state that VOT fail to separate Korean stop categories, rather they mentioned that it could separate aspirated set from the other two, and may well be the single most important measure for separating the latter. Hence, it can be inferred that Korean stop categories can be separated by aspiration noise, forgetting not that they had mentioned that 'none of the acoustic features which have been suggested as correlates of a fortis/lenis dimension demonstrably independent of voicing'. On the contrary, Kim (1973: 355-365) refuted their arguments and proposed that the primary differentiating feature of Korean stops is the "tension" of the articulation. The languages having four opposition types are Hindi and Marathi. One differentiating aspect of these two languages from the rest is this: aspiration is 
found in voiceless stops and voiced ones. 'It was in these two languages that the measure of voice onset time fell short to distinguish stop categories', Lisker and Abramson stated. Moreover, overlap in the VOT value between voiced unaspirated stops and voiced aspirated were seen.

\subsection{VOT Patterns of English and Arabic}

Although Arabic and English are two-category languages (Lisker \& Abramson, 1964: 388 cited in Khattab: 2000), it has been reported that both languages exhibit different VOT patterns. In Arabic, for instance, Yeni-Komshian, Caramazza, and Preston (1977) reported on Lebanese Arabic stops word-initially before /a, i, u/ vowels. They found out that voiced stops are characterized by the predominance of voicing lead; while voiceless stops fall in the short lag range. However, they found that there were overlapping for the pairs $/ t, d /$ and $/ \mathrm{t}^{\mathrm{\complement}}, \mathrm{d}^{\mathrm{\varsigma}} /$. In his study of Colloquial Egyptian Arabic (CEA), Rifaat (2003) has found that CEA has two VOT patterns namely; long lead for voiced stops and short lag for voiceless stops. Furthermore, the separation between voiced and voiceless stops was without any overlapping observed. AlDahri (2013) investigated two emphatic stops, $/ \mathrm{d}^{2} / \& / \mathrm{t}^{2} /$, and two non-emphatic coronal stops, $/ \mathrm{d} / \&$ $/ \mathrm{t} /$, as counterparts to the formers. He analyzed the four stops in carrier words of a syllable structure CV-CV-CV. He concentrated on analyzing and computing VOT of Modern Standard Arabic (MSA). Part of his findings is that the emphatic stops $/ \mathrm{d}^{?} / \& / \mathrm{t}^{2} /$ are less than $50 \%$ of their non-emphatic counterpart sounds /d/ \& /t/. In 2012, Aldahri also investigated VOT of MSA and Classical Arabic (CA). His experiment revealed three major outcomes. The first is that the VOT is always positive regardless of voicing. The second one is that VOT occupies the short lag for voiced stops and the long lag region for voiceless ones. The third finding is that VOT values showed different values for different Arabic dialects. Flege and Port (1981) compared voiceless stops of Saudi Arabic with voiceless stops of American English. The result of their study showed that the VOT of /t, k/ of Saudi Arabic are somewhat shorter than their counterparts in American English. Al-Nuzaili (1993) investigated VOT in Yemeni Arabic; he found that voiced stops occupy the lead continuum while voiceless stops are scattered in the lag region. Al-Malwi (2017) found that voiceless stops of Abha Arabic have a long lag VOT pattern and voiced non-emphatic stops have a long lead. On the other hand, Lisker \& Abramson (1971: 767) and Ladefoged \& Maddieson (1996) reported that VOT patterns of Voiced English stops occupy the short lag continuum while voiceless stops fall in the long lag continuum. Unlike Arabic, in which the phonemic pairs $/ \mathrm{t}, \mathrm{d} / \mathrm{and} / \mathrm{k}, \mathrm{g} / \mathrm{can}$ be distinguished by presence or absence of the vocal pulsing, English phonemic pairs /p, b/; / , d/ and /k, g/ may lack voicing word-initially before vowels (Lisker, \& Abramson, 1964: 385). Therefore, other dimensions such as aspiration were needed for separating them. The timing differences between glottal and supraglottal events (Brown, 1977: 30; Ladefoged \& Maddieson, 1996: 50) and aspiration are needed to separate word-initial $/ \mathrm{b}, \mathrm{d}, \mathrm{g} /$. Figure 1 below represents the relationship of the VOT patterns between English and Arabic. The Arabic VOT patterns shown in the figure is based on the findings of both Al-Nuzaili (1993) and Yeni-Komshian et. al. (1997). 


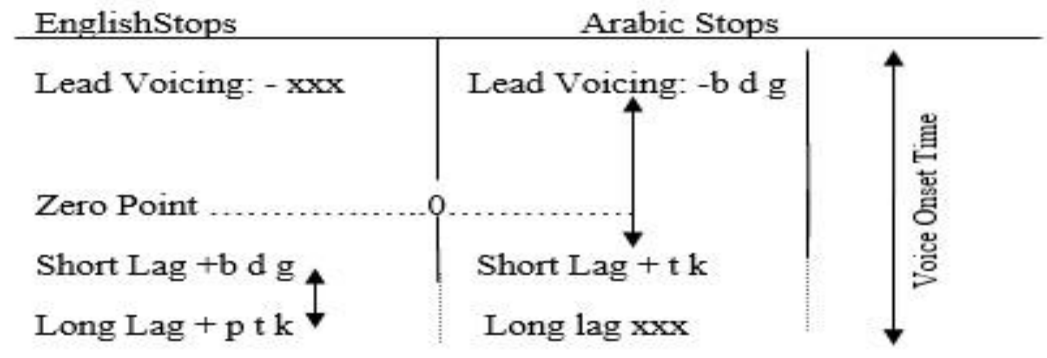

Figure 1. Schematic Representation of the VOT patterns, which shows the relationship between English and Arabic stops

\subsection{Some Effects on VOT}

Phoneticians have reported a good number of factors (physiological/aerodynamic) which affect VOT productions. Some of these, which I consider the most prominent ones, are the place of articulation-related factors. The salient findings concerning place of articulation are: the further back the closure, the longer the VOT (Fischer Jørgensen, 1954; Peterson \& Lehisite, 1960; Lisker \& Abramson, 1964; Yeni-Komshian, 1977; Hardcastle, 1973; Cooper, 1991; Nearey \& Rochet, 1994; Weismer, 1979); the more extended the contact area, the longer the VOT (Stevens \& Kawasaki, 1986); and the faster the movement of the articulator, the shorter the VOT (Hardcastle, 1973). Considering the reasons behind the length and shortness of VOT in the above three points; Cho and Ladefoged (1999) accounted for the first point in the volume of the cavity both behind and in front of the constriction. First, the volume of the cavity behind velar closure is smaller than that of the alveolar or bilabial. As a result, it causes a greater pressure, which takes longer to fall and allow enough transglottal pressure for the initiation of vocal cord vibration. Second, the volume of the cavity in front of the velar closure is longer than that of the alveolar, therefore the pressure will take longer to fall and result in a delay in producing enough transglottal pressure. The same authors also stated that the more extended contact area results in a slower release; consequently, it takes a longer time before an adequate transglottal pressure is produced. Moreover, because the articulators come apart more slowly there is a long time before an appropriate transglottal pressure is produced. In respect of the third point, they hold that the fast velocity of the articulators leads to a rapid decrease in air pressure built behind the constriction area, which leads to a short VOT. In addition to the three points mentioned above, Cho and Ladefoged (Ibid) stated that the change in the glottal opening cause variation in VOT. For example, the glottal opening area after the release of the voiceless aspirated stops will decrease less rapidly for the velar than for the alveolar or labial because the intraoral pressure drops more slowly for the velar.

Many other factors are reported to affect VOT. For instance, Hoit, Solomon, and Hixon (1993) have found that VOT is longer at high lung volumes. Lisker and Abramson (1967) demonstrated that the separation between $/ \mathrm{b}, \mathrm{d}, \mathrm{g} /$ and $/ \mathrm{p}, \mathrm{t}, \mathrm{k} /$ is less sharp in running speech than in isolated forms; there is some overlap along the dimension of VOT. They discussed the extent to which certain contextual features are responsible for this overlap. Social factors have also been reported to affect VOT patterns. Almalwai (2017) has found that age and gender have a significant effect on VOT. Moreover, he indicated that children achieve adult-like VOTs at age 10 to 12 years old. Robb, Gilbert, Lerman (2005) in their study of six stop consonant in CV syllable, followed by three different vowels, have shown that gender and environmental setting 
(e.g. place) have an influence on VOT. According to them, females produced voiceless stops with significantly longer VOT durations than males in both a laboratory and a non-laboratory setting. They furthermore noticed that both males and females have longer VOT in laboratory settings than in non-laboratory settings. Robb et. al. also observed that speaking style contributes to gender differences in speaking behavior in the production of VOT.

\section{MEASUREMENT PROCEDURES}

VOT is measured following Lisker and Abramson $(1964 ; 1967)$ studies: if the pulsing started during the consonantal closure and continued until the stop release, then it is an instance of a voicing lead. But if it starts after the release, then it is a voicing lag. In stating the value of the VOT, a zero value was assigned to the instant of burst onset; positive numbers were assigned to the time interval by which voice onset lags behind the release and negative numbers of milliseconds are assigned to the voice onset which leads the release of the stop consonants (Lisker and Abramson 1967). For this study, the measurements were made on a wideband spectrogram and crossed checked with waveforms. Like Khattab (2002), the VOTs of prevoiced stops were measured 'from the onset of the first periodic cycle in the closure period to the beginning of the release burst'. The VOTs of voiceless stops were measured from the onset of stop release to the beginning of quasi-periodicity.

A total number of 206 word-carriers in citation form were recorded in the acoustic lab of the center of advance study in linguistics (CAS) at Annamalai University. Every word was repeated thrice. The mean value of the three repetitions is shown in the appendices (e.g., A, B, and $\mathrm{C}$ ) while the mean value of every sound in all contexts is shown in index $D$, table $2 \& 3$. All the mean value of all tokens of each sound followed by short vs. long vowels are shown in table $5 \& 6$ for the first subject Ramzi, while the mean value of all tokens of each sound followed by short vs. long vowels for the second subject, Fadhl is shown in table $7 \& 8$. All the words recorded were rehearsed before recording sessions to reduce the effect of suprasegmental factors. One hundred and three words-stimuli were recorded by each speaker: Fadhl and Ramzi. For the latter; however, five tokens were excluded due to the noise (e.g., knocking door) encountered during recording sessions. The bulky number of words was recorded in four sessions for each of the speakers. In each session, around 25 words typed on card papers, to avoid noise, are recorded followed by a five minutes break. Some words are repeated in different sessions to see if there is a difference in their VOT values. The sampling frequency of each recorded word is $22050 \mathrm{~Hz}$ and 16-bit quantization. The measurement process was made by using the software program Praat (Boersma, 2001). The words are read from the folders containing them into Praat, and annotated into a text grid. Then each word is viewed and edited, measured and labeled. The VOT values of each stop consonant followed by a vowel in carrier words are saved along with the name of the words and its VOT value. When I completed the measurements, I inserted all values of each word manually into excel software, wherein the mean values of each three-times repetitions are calculated along with ranges, mode, and median. Furthermore, with the help of coloring cells, it was easy to sort the data (e.g. VOT values, following vowels: short vs. long) based on cell color.

\section{RESULTS AND DISCUSSION}

Figure 2 below shows the distribution of VOT while tables 2 and 3 below summarize the mean and range of VOT values for the six English stops as produced by two Yemeni Adults. It 
can be seen in table 2 and figure $2(\mathrm{~A}, \mathrm{~B}, \mathrm{C})$ that there is no overlapping on any of the homorganic pairs /p, b/, /t, d/ and /k, g/ as produced by Fadhl, the first subject. All voiceless stops are assigned positive values while all voiced stops are assigned negative values.

Table 2. VOT mean, range and counts of tokens as produced by Fadhl

\begin{tabular}{lcccccc}
\hline Segment & $/ \mathbf{p} /$ & $/ \mathbf{t} /$ & $/ \mathbf{k} /$ & $/ \mathbf{b} /$ & $/ \mathbf{d} /$ & $/ \mathbf{g} /$ \\
\hline Mean & 48.72 & 32.22 & 43.66 & -81.82 & -85.87 & -101.5 \\
\hline Range & $26 / 83$ & $19 / 59$ & $22 / 99$ & $-13 /-131$ & $-50 /-13 C$ & $-70 /-148$ \\
\hline Count & 18 & 18 & 18 & 17 & 16 & 16 \\
\hline
\end{tabular}

However, the distribution of VOT values for Ramzi, the second subject, shows that there is a noticeable overlapping in the region of VOT continuum during the production of word-initial homorganic stops, /p $\mathrm{b} /$ pair. Four out of seventeen tokens show that $/ \mathrm{p} /$ has a lead pattern and is assigned negative VOT values as can be seen in figure 2 (D) below.

Table 3. VOT mean, range, and counts of tokens as produced by Ramzi

\begin{tabular}{lcccccc}
\hline Segment & $/ \mathbf{p} /$ & $/ \mathbf{t} /$ & $/ \mathbf{k} /$ & $/ \mathbf{b} /$ & $/ \mathbf{d} /$ & $/ \mathbf{g} /$ \\
\hline Mean & 31.11 & 50.70 & 70.18 & -72.47 & -101.29 & -87.71 \\
\hline Range & $-78 / 81$ & $25 / 86$ & $37 / 133$ & $10 /-112$ & $-43 /-173$ & $-65 /-109$ \\
\hline Count & 17 & 17 & 16 & 17 & 17 & 14 \\
\hline
\end{tabular}
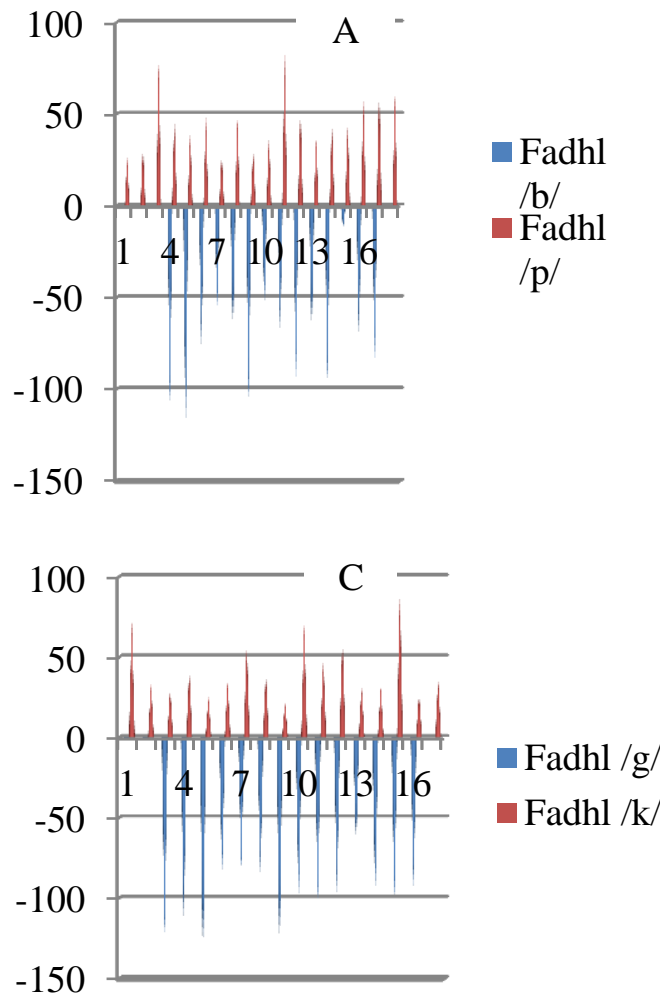

- Fadhl /b/ - Fadhl $/ \mathrm{p} /$

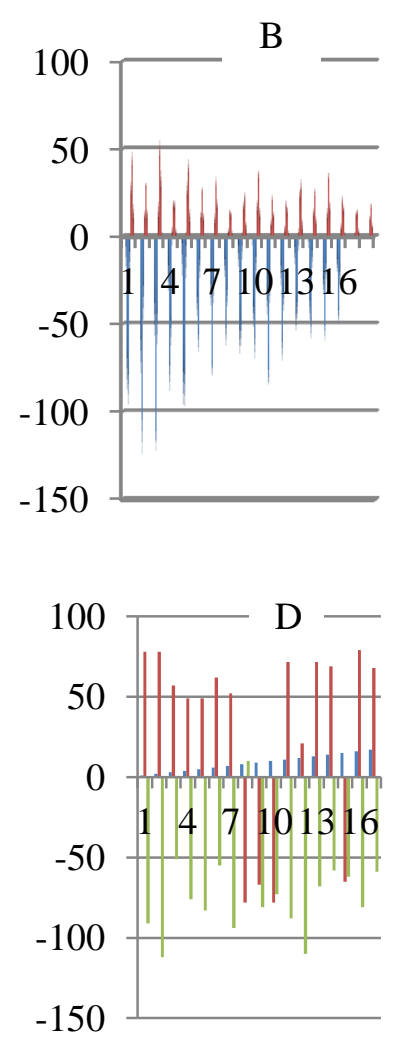

— Fadhl /d/

- Fadhl /t/

No.

- Ramzi /p/ value

Ramzi /b/ value 


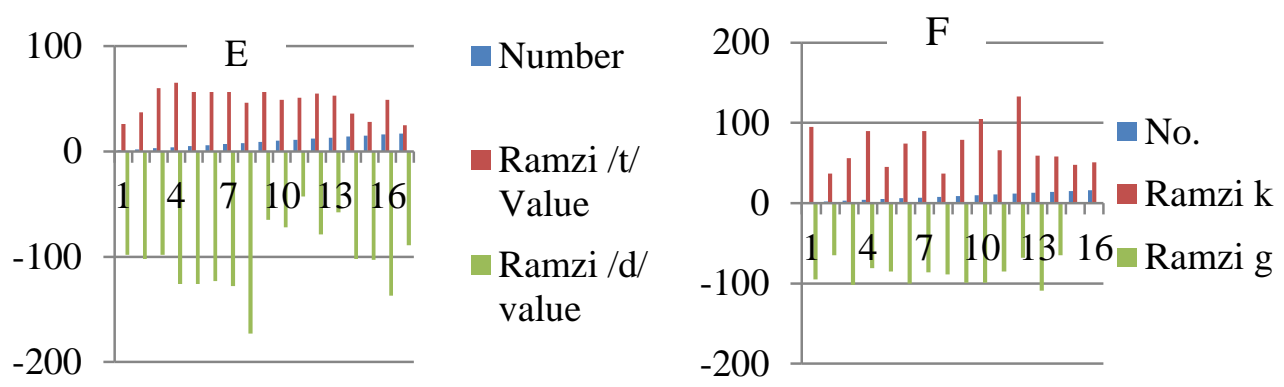

Figure 2. VOT distributions for the production of the six stops in word-initial as per the two speakers: Fadhl and Ramzi
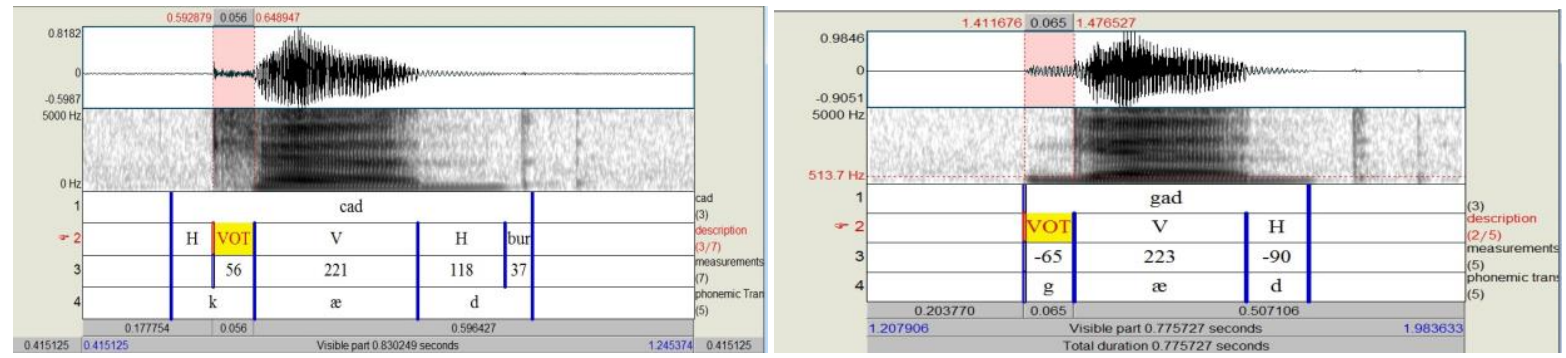

Figure 3. (A) /kæd/ as produced by Ramzi. Figure 3. (B) /gæd/ as produced by Ramzi

The result shows that the homorganic stop categories (e.g., /t/ vs. /d/) can be separated by the presence or absence of vocal pulsing as shown in figure 3 (A \& B) above. The VOT in the above figures $(A \& B)$ shows that the VOT as an acoustic correlate of voicing succeeds in distinguishing between the voiceless alveolar $/ \mathrm{t} /$ and the voiced alveolar $/ \mathrm{d} /$. The VOT distribution revealed that the stop produced by NYASE utilize two VOT patterns namely: long lead and long lag continuum as schematized in figure 4. Whereas the voiced stops are produced with a long lead voicing, the voiceless ones are produced with a long lag VOT pattern. Ostensibly, both speakers maintain their mother tongue VOT continuum for the voiced stops and the second language, English, continuum for voiceless ones. However, it has been reported in the review that the VOT pattern for voiced English stops as produced by the native speakers occupies the short lag continuum while voiceless stopss fall in the long lag position (Lisker and Abramson, 1964, 1967) as shown in figure 1 earlier. Based on this result, it can be inferred that English language as produced by NYASE belong neither to group $A$ languages nor to group $B$. These findings are consistent with Al-Malwi (2017) study of Abha Arabic when it comes to non-emphatic stops. Al-Malwi found that voiceless stops have a long lag VOT pattern and voiced non-emphatic stops have a lead pattern. 


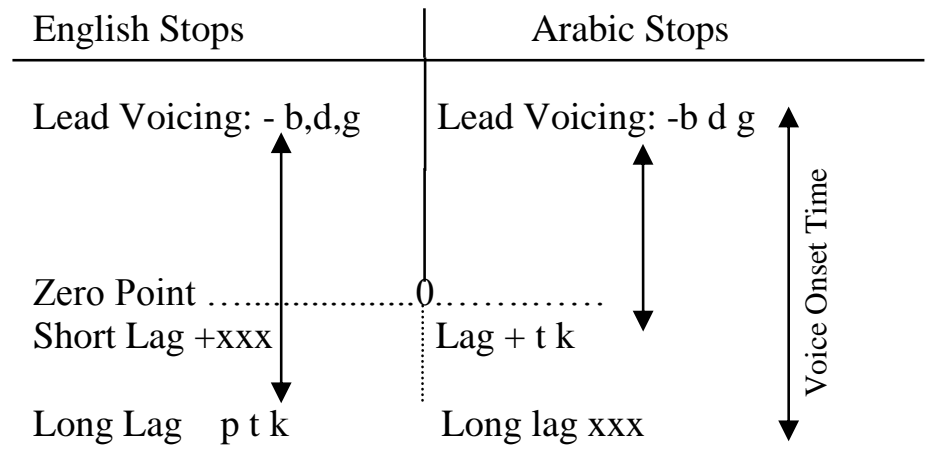

Figure 4. A schematic Representation of VOT Patterns for the Six English Stops as Produced by NYASE

On the other hand, the voicing alone has also been reported to fall short for separating homorganic contrastive pairs word-initially and pre-vocalically in English (Lisker \& Abramson, 1964: 527). As a consequence, phoneticians invoked another dimension namely; an aspiration to separate such pairs. In this study, the voicing distinction could stand alone as a single dimension capable of separating voiceless from voiced stops. Although it was noticed that there was an overlap in the production of /p/ for Ramzi, I assume that this overlapping is not a result of the following vowels or any other contextual factors as the measurements have shown. Rather, it was as a consequence of the influence of the mother tongue on the sound /p/. Because the Arabic language lacks voiceless bilabial stop /p/, the speaker fails to apply the fine-grained phonetic details in all environments.

\subsection{Place of Articulation and Vocalic Context}

This section is devoted to reviewing what is reported in the literature about the place of articulation of stop consonants. It has been reported earlier in the literature that the further back the place of articulation of voiceless stops, the longer the VOT (e.g., Yeni-Komshian, 1977). For the first subject Fadhl, the voiceless velar stop /k/ has a higher VOT mean value of 43.66 than voiceless alveolar / $\mathrm{t} /$, which has 32.22 mean value. This finding supports the above principle in part because the voiceless bilabial stop /p/ has the highest mean value (48.72) than velar and alveolar (c.f. appendix $D$ ). The reason why $/ \mathrm{p} /$ has the highest mean value for the first subject is that the movement of the articulators responsible for the production of $/ \mathrm{p} /$ comes apart very slowly (Hardcastle, 1973). Another reason for this phenomenon can be more logical, however. Knowingly, that $/ \mathrm{p} /$ is not in the phonemic system of the Arabic language, the speaker; therefore, lacks the fine-grained phonetic details of pronouncing this phoneme accurately in the second language. However, for the second subject Ramzi, velar $/ \mathrm{k} /$ has a 70.18 mean value. It is the highest value among voiceless stops. Voiceless alveolar /t/ has 50.7 mean value, higher than voiceless bilabial stop /p/, which has 31.11 VOT mean value (See appendix $D)$. This goes in a total agreement with the principle referred to above regarding place of articulation. Hardcastle referred to two possibilities, which account for such systematic variation. The first is the slower movement of the back of the tongue in velar than the tip of the tongue for alveolar (e.g., /t/) or bilabial (e.g., /p/). The second possibility is the amount of supraglottal pressure; that the pressure is greater behind the velum than behind alveolar constriction or the lips. 
Table 5. The VOT Mean Values for the Stop Consonants Followed by Short/Long Vowels as Produced by Fadhl

\begin{tabular}{ccccccc}
\hline Segment & \multicolumn{2}{c}{$/ \mathbf{p} /$} & \multicolumn{2}{c}{$/ \mathbf{t} /$} & \multicolumn{2}{c}{$/ \mathbf{k} /$} \\
\hline Context & Long V. & Short V. & Long V. & Short V. & Long V. & Short V. \\
\hline Mean & 52.83 & 40.5 & 34.14 & 25.5 & 45 & 30.8 \\
\hline Count & 12 & 6 & 14 & 4 & 12 & 5 \\
\hline Segment & \multicolumn{2}{c}{ /b/ } & \multicolumn{2}{c}{$/ \mathbf{d} /$} & \multicolumn{2}{c}{$/ \mathbf{g} /$} \\
\hline Context & Long V. & Short V. & Long V. & Short V. & Long V. & Short V. \\
\hline Mean & -82.76 & -78.75 & -90 & -75 & -107.08 & -103.25 \\
\hline Count & 13 & 4 & 11 & 5 & 12 & 4 \\
\hline
\end{tabular}

Though this paper is not meant to account for vocalic context, the following are the findings of the influence of vowels following word-initial stops. Two factors are considered here. The first is the 'length' of the vowel and the second is 'height'. Relating to the first subject, Fadhl, all VOT mean values for stops followed by long vowels are longer than those which are followed by short vowels for all stop categories. All VOT mean values for voiceless stops are shorter than their counterparts, voiced stops; be that they are followed by long or short vowels. /t/ has the lowest VOT mean value when followed by short vowels than any other voiceless stops. On the other hand, /g/ has the highest VOT mean values when followed by long vowels than any other voiced stops. This finding shows how significant it is to consider 'length' as a factor that has a significant influence on VOT mean values. Voiceless bilabial stop / $\mathrm{p} / \mathrm{has}$ the highest VOT mean value when followed by long vowel than any other voiceless stops. Voiceless alveolar stop /t/ fall in short lag continuum when it is followed by short vowels. All these variances in VOT values emphasize the need for considering the length of vowels that follow the stops in investigating the context of VOT.

Table 6. The VOT Mean Values for the Stop Consonants Followed by Short/Long Vowels as Produced by Ramzi

\begin{tabular}{cccccccc}
\hline Segment & \multicolumn{9}{c}{ /p/ } & \multicolumn{1}{c}{$/ \mathbf{t} /$} & /k/ \\
\hline Context & Short & Long & Short & Long & Short & Long \\
\hline Mean & -16.5 & 57.09 & 44 & 54.55 & 51.25 & 79.09 \\
\hline Count & 6 & 11 & 4 & 9 & 4 & 11 \\
\hline Segment & \multicolumn{2}{c}{ /b/ } & \multicolumn{2}{c}{$/ \mathbf{d} /$} & \multicolumn{2}{c}{$/ \mathbf{g} /$} \\
\hline Context & Short & Long & Short & Long & Short & Long \\
\hline Mean & -82 & -70.42 & -44 & -52.76 & -89.66 & -87.18 \\
\hline Count & 3 & 14 & 4 & 13 & 3 & 11 \\
\hline
\end{tabular}

For the second subject, Ramzi, all voiceless stops followed by long vowels have longer VOT values than voiceless stops followed by short vowels. In voiced stops; however, it is only /d/ followed by long vowels that has longer value than /d/ followed by short vowels. Both /b/ and $\mathrm{lg} /$ showed shorter values when followed by long vowels than when they are followed by short vowels. Furthermore, voiceless velar stop /k/ has the highest VOT mean value than all other voiceless stops when followed by long vowels. On the contrary, voiced velar stop /g/ has the 
highest mean value when followed by short vowels. This goes in contradiction with what was found with Fadhl. In the case of Fadhl, /g/ has the highest VOT mean value when it is followed by long vowels. This contradiction suggests that there are individual differences and that the result cannot be generalized. These differences can either exist in the anatomical structure of the speakers or the social and dialectical factors. Finally, the mean value for the voiceless bilabial stop /p/ occupies the lead VOT pattern when followed by short vowels. It is worth noting that words repeated in different sessions have different VOT values for stop consonants in word-initial position. The difference; however, does not change their position on the VOT continuum.

As can be seen in the following tables: $(7 \& 8)$ that the VOT mean values for stops followed by high vowels (i:, i, u:, u) are higher than the VOT mean values followed by low vowels $(\mathrm{a}, \mathfrak{x})$ for both subjects, but this is not without exception. For instance, in the table (7), /d/ has a longer VOT value before low vowels than before high vowels. This difference; however, is very slight, -2.04 .

Table 7. High Vs. Low Context of Fadhl's production

\begin{tabular}{cccc}
\hline Mean Value & $\begin{array}{c}\text { Before High } \\
\text { Vowels }\end{array}$ & $\begin{array}{c}\text { Before Low } \\
\text { Vowels }\end{array}$ & $\begin{array}{c}\text { Difference } \\
(\mathbf{m s})\end{array}$ \\
\hline$/ \mathbf{p} /$ & 50.84 & 43.2 & 7.64 \\
\hline$/ \mathbf{b} /$ & -93 & -61.33 & -31.67 \\
\hline$/ \mathbf{t} /$ & 37 & 24.71 & 12.29 \\
\hline$/ \mathbf{d} /$ & -87.16 & -89.2 & -2.04 \\
\hline$/ \mathbf{k} /$ & 50.45 & 33 & 17.45 \\
\hline$/ \mathbf{g} /$ & -110.75 & -105.33 & 5.42 \\
\hline
\end{tabular}

In table (8) the VOT mean value for the six stops is higher before high vowels than it is before low vowels. The shortest differences are those of $/ \mathrm{t} /$ and $/ \mathrm{g} /$. The difference between /t/ followed by high vowels and /t/ followed by low vowels is $3.4 \mathrm{mse}$. Similarly, the difference between /g/ followed by high vowels and /g/ followed by low vowels is $1.83 \mathrm{mse}$. The difference between all other stops ranges from 14 to 18 mse for voiceless stops and from -14 to -22 for voiced stops.

Table 8. High vs. Low Context of Ramzi's Production

\begin{tabular}{cccc} 
VOT Mean Value & $\begin{array}{c}\text { Before High } \\
\text { Vowels }\end{array}$ & $\begin{array}{c}\text { Before Low } \\
\text { Vowels }\end{array}$ & $\begin{array}{c}\text { Difference } \\
(\mathbf{m s})\end{array}$ \\
\hline$/ \mathbf{p} /$ & $67.22 *$ & 53 & 14.22 \\
\hline$/ \mathbf{b} /$ & -75.72 & -66.5 & -14.22 \\
\hline$/ \mathbf{t} /$ & 51.9 & 48.5 & 3.4 \\
\hline$/ \mathbf{d} /$ & -105.28 & -82.66 & -22.62 \\
\hline$/ \mathbf{k} /$ & 77 & 58.83 & 18.17 \\
\hline$/ \mathbf{g} /$ & -87.33 & 85.5 & 1.83 \\
\hline
\end{tabular}




\section{CONCLUSION}

This paper investigated six English stops as produced by NYASE. The results showed that NYASE utilized two VOT patterns; voiced stops fall in the lead region, and voiceless stops fall in the long lag region. There was not any overlapping seen during the production of the six stops produced by the first subject Fadhl. However, overlapping was seen during the production of /p/ by Ramzi. Utterances repeated in different sessions show a slight variation in their VOT mean values. Yet, the variation does not change their place on the VOT continuum. To the best of my knowledge, no work has been dedicated to investigate English stops as produced by native Yemeni Arabic. This paper; therefore, constitutes the basis for enriching the topic area and urges researchers interested in the field to investigate stops in terms of VOT in both Arabic and English language. Not only that, but it also urges researchers to make an indepth inquiry of the topic in citation forms and frequent speech in different dialects of Yemen. Finally, this paper has its limitations. For instance, (1) it only focuses on word-initial stop consonants and pre-vocalically but not in a medial and final position; (2) It is limited to English stops in their citation form without any reference to frequent speech, which is deemed to be more natural.

\section{REFERENCES}

Al-Ani, Salman. (1970). Arabic Phonology. The Hague: Mouton.

Abramson, A. S. (1995). Laryngeal timing in Karen obstruents. In F. Bell-Berit \& L. Rafael (Eds.), Producing speech: Contemporary issues. For Katherine Safford Harris (pp.155- 165). Woodbury, NY: American Institute of Physics Press.

AlDahri, S. (2013). A study for the effect of the emphaticness and language and dialect for voice onset time (VOT) in Modern Standard Arabic (MSA). Signal \& Image Processing, 4(2), 11-29.

Aldahri, S. S. 2012. A study of voice onset time for modern standard Arabic and classical Arabic 691-695.

Al Malwai, M., I. (2017). The effects of gender and age on voice onset time by Abha Arabic speakers. MA, Thesis, California State University, Long Beach.

Al-Masri, M. \& Allard J. (2004). Acoustic Correlates of Emphasis in Jordanian Arabic: Preliminary results. Proceedings of the 2003 Texas Linguistics Society Conference, ed. by Augustine Agwuele et al., 96-106. Somerville, Massachusetts: Cascadilla Proceedings Project. www.lingref.com, document \#1071.

Agnello J, Wingate ME,Wendell M. (1974). Voice onset and termination times of children and adult stutterers. Journal of the Acoustical Society of America, 56:697.

Al-Nuzaili, Abdulrahman M. (1993). Experimental Study of Emphasis and Voicing in the Plosives of Yemeni Spoken Arabic. Ph.D. dissertation, University of Leeds.

Boersma, P., \& Weenink, D. (2016). Praat: doing phonetics by computer [Computer program]. Version 6.0.21. Retrieved 25 April 2016 from: http://www.praat.org/

Campbell, Thomas \& A. Dollaghan, Christine. (1995). Speaking Rate, Articulatory, Speed, and Linguistic Processing in Children and Adolescents with Severe Traumatic Brain Injury. Journal of speech and hearing research. 38. 864-75. 
Caramazza, A., Yeni-Komshian G., H., Zurif, E. B. \& Carbone, E. (1973). The acquisition of a new phonological contrast: the case of stop consonants in French- English bilinguals. Journal of the acoustical society of America, 54, 421-428.

Caramazza, A., Yeni-Komshian, G. H. (1974). Voice onset time in two French dialects. Journal of Phonetics, 2, 239-245.

Chao, K., \& Chen, L. (2008). A cross-linguistic study of voice onset time in stop consonant productions. Computational Linguistics and Chinese Language Processing, 13(2),215232. Retrieved from: http://www.aclweb.org/ anthology /O/ O08/O08-4005.

Cho \& Ladefoged (1999).Variation and universals in VOT: evidence from 18 languages. Journal of Phonetics, 27, 207-229.

Deuchar, M. \& Clark, A. (1996). Early bilingual acquisition of the voicing contrast in English and Spanish. Journal of Phonetics, 24, 351-365.

DiSimoni, F. (1974). Preliminary study of certain timing relationships in the speech of stutterers. Journal of the Acoustic Society of America, 56, 695-696.

Docherty, G. J. (1992). The timing of voicing in British English obstruents. Berlin/New York: Foris.

Farmer A, Brayton ER. (1979). Speech characteristics of fluent and non-fluent Down's Syndrome adults. Folia Phoniatrica 31, 284-90.

Flege, J. E., (1979) Phonetic interference in second language acquisition, Unpublished Ph. D. Thesis, Indiana University, Bloomington.

Flege, J., \& Port, R. (1981). Cross-language phonetic interference: Arabic to English. Language and Speech, 24, 125-146. doi:10.1177/002383098102400202.

Hardcastle, W. J. (1973) Some observations on the Tense-Lax distinction in initial stops in Korean. Journal of Phonetics, 1, 263-271.

Hoit, J. D., Solomon, N. P., and Hixon, T. J. (1993). Effect of Lung Volume on Voice Onset Time (VOT). Journal of Speech and Hearing Research, 36, 516-521.

Kelso, J. A. S., \& Tuller, B. (1985). Intrinsic time in speech production: Theory, methodology, and preliminary observations (HaskinsLaboratories Status Report on Speech Research SR-81, pp. 23- 39. New Haven, CT: Haskins Laboratories.

Kessinger, R. H., \& Blumstein, S. E. (1998). Effects of speaking rate on voice-onset time and vowel production: Some implications for perception studies. Journal of Phonetics, 26, 117-128.

Khattab, G. (2000) VOT Production in English and Arabic Bilingual and Monolingual Children. Leeds Working Papers in Linguistics and Phonetics, 8, 95-122.

Khattab, G., F. Al-Tamimi and B. Heselwood. (2006). Acoustic and auditory differences in the /t/- /T/ opposition in male and female speakers of Jordanian Arabic. In S.Boudelaa (Ed.),Perspectives on Arabic Linguistics XVI: Papers from the sixteenth annual symposium on Arabic linguistics, 131-160.Cambridge, UK: John Benjamins.

Kim, C. W. (1965). On the autonomy of the tensity feature in stop classification with special reference to Korean stops. Word, 21: 339-359.

Klatt, D.(1975). Voice onset time, frication and aspiration in word-initial consonant clusters. Journal of Speech and Hearing Research, 18, 686-705. 
Ladefoged, P. \& Maddieson, I. (1996) Sounds of the worlds languages. Oxford: Blackwells.

Lam, C. [林松齡. (2010). Effect of tones on voice onset time (VOT) in Cantonese aspirated stops. (Thesis). University of Hong Kong, Pokfulam, Hong Kong SAR.

Lehiste, I. (1965). Some acoustic characteristics of dysarthric speech. Biblioteca Phonetica. 2, 1-124.

Lisker, L., \& Abramson, A. S. (1964). A crosslinguistic study of voicing in initial stops:

Acoustical Measurements. Word 20, 384-422.

Lisker, L. \& Abramson A. S. (1964). A cross-language study of voicing in initial stops:

Acoustical measurements. Word 20 (3). 527-565. Reprinted, with permission from John

R. Costello, Editor, WORD.

Lisker, L., and Abramson, A.S. (1967). Some effects of context on voice onset time in English stops. Language and Speech, 10,1-28.

Magloire, J., \& Green, K. P. (1999). A cross-language comparison of speaking rate effects on the production of voice onset time in English and Spanish. Phonetica, 56, 158-185.

Miller, J. L., \& Baer, T. (1983). Some effects of speaking rate on the production of /b/ and /w/. Journal of the Acoustical Society of America, 73, 1751-1755.

Miller, J. L., \& Volaitis, L. E. (1989). Effect of speaking rate on the perceptual structure of a phonetic category. Perception \& Psychophysics, 46, 505-512.

Mitleb, F. (2001). Voice onset time of Jordanian Arabic stops. Journal of the Acoustical Society of America, 109(5), 133-135.

Mitleb, F. (2009) Voice onset time of Jordanian Arabic stops, The 3rd International Conference on Arabic Language Processing (CITALA'09), Rabat, Morocco, pp. 133-135.

Port, R.F. and R. Rotunno, "Relation Between Voice-Onset Time and Vowel Duration," Journal of the Acoustical Society of America, 66, 1979, 654-662.

Rifaat, K. 2003. Voice Onset Time in Egyptian Arabic : A Case where Phonological Categories Dominate. Linguistique, 791-794.

Robb M, Gilbert H, Lerman J: Influence of Gender and Environmental Setting on Voice Onset Time. Folia Phoniatr Logop 2005; 57:125 -133. doi: 10.1159/000084133.

Shitaw, A. E. 2014. An instrumental phonetic investigation of timing relations in two stop consonant clusters in tripolitanian libyan Arabic. Ph.D. Dissertation, University of Leeds.

Sundara, M., Polka, L., \& Genesee, F. (2006). Language experience facilitates discrimination of /d- ð/ in monolingual and bilingual acquisition of English. Cognition, 100, 369-388.

Tamim, N. (2017). Voicing Contrast of Stops in the Palestinian Arabic Dialect. MA Thesis, Universiteit Van Amsterdam.

Tillmann, H. G. (1995). Early modern instrumental phonetics. In E. F. K. Koerner \& R. E. Asher (Eds.), Concise history of the language sciences: From the Sumerians to the cognitivists (pp. 401-416). Oxford: Pergamon.

Viswanath NS, Nee1 AT. (1995) Part-word repetitions by persons who stutter: fragment types and their articulatory processes. Journal of Speech and Hearing research, 38: 740-50. 
Yeni-Komshian, G. H. Caramazza, A. and Preston, M.S. (1977). A study of voicing in Lebanese Arabic. J. of Phon. 5: 35-48.

Yu, V. Y., De Nil, L. F., \& Pang, E. W. (2015). Effects of age, sex and syllable structure on voice onset time: Evidence from children's voiceless aspirated stops. Language and Speech, 58(Pt 2), $152-167$.

\section{APPENDIX}

A.

Ramzi's production of Voiceless stops in following words

\begin{tabular}{|c|c|c|c|c|c|c|}
\hline \multirow[t]{2}{*}{ No. } & \multirow[t]{2}{*}{ Word } & \multicolumn{2}{|c|}{ VOT } & \multirow[t]{2}{*}{ Sound } & \multirow[t]{2}{*}{ F.V } & \multirow[t]{2}{*}{ C.F.V } \\
\hline & & Positive & Negative & & & \\
\hline 1 & $\mathrm{P}$ & 78 & & $\mathrm{p}$ & i: & None \\
\hline 2 & Two & 26 & & $\mathrm{t}$ & $\mathrm{u}:$ & None \\
\hline 3 & Key & 95 & & $\mathrm{k}$ & i: & None \\
\hline 4 & Peak & 78 & & $\mathrm{p}$ & i: & K \\
\hline 5 & Tick & 37 & & $\mathrm{t}$ & $\mathrm{i}$ & $\mathrm{K}$ \\
\hline 6 & Can & 37 & & $\mathrm{k}$ & $æ$ & $\mathrm{~N}$ \\
\hline 7 & Peat & 57 & & $\mathrm{p}$ & i: & $\mathrm{T}$ \\
\hline 8 & Teak & 60 & & $\mathrm{t}$ & i: & K \\
\hline 9 & $\mathrm{Cad}$ & 56 & & $\mathrm{k}$ & $æ$ & $\mathrm{D}$ \\
\hline 10 & $\mathrm{~Pa}$ & 49 & & $\mathrm{p}$ & $\mathrm{a}$ & None \\
\hline 11 & Took & 65 & & $\mathrm{t}$ & $\mathrm{u}$ & $\mathrm{K}$ \\
\hline 12 & Cap & 90 & & $\mathrm{k}$ & $æ$ & $\mathrm{P}$ \\
\hline 13 & Pad & 49 & & $\mathrm{p}$ & $æ$ & $\mathrm{D}$ \\
\hline 14 & Tea & 63 & & $\mathrm{t}$ & $\mathrm{i}:$ & None \\
\hline 15 & $\mathrm{Cab}$ & 45 & & $\mathrm{k}$ & $æ$ & $\mathrm{~B}$ \\
\hline 16 & Pack & 62 & & $\mathrm{p}$ & $æ$ & $\mathrm{~K}$ \\
\hline 17 & Tag & 66 & & $\mathrm{t}$ & $æ$ & G \\
\hline 18 & Cat & 74 & & $\mathrm{k}$ & $æ$ & $\mathrm{~T}$ \\
\hline 19 & $\mathrm{~Pa}$ & 52 & & $\mathrm{p}$ & $\mathrm{a}$ & None \\
\hline 20 & Tad & 67 & & $\mathrm{t}$ & $æ$ & $\mathrm{D}$ \\
\hline
\end{tabular}




\begin{tabular}{|c|c|c|c|c|c|c|}
\hline 21 & Key & 90 & & $\mathrm{k}$ & i: & none \\
\hline 22 & Tat & 46 & & $\mathrm{t}$ & $æ$ & $\mathrm{t}$ \\
\hline 23 & Could & 37 & & $\mathrm{k}$ & $\mathrm{u}$ & $\mathrm{d}$ \\
\hline 24 & Pit & & 78 & $\mathrm{p}$ & $\mathrm{i}$ & $\mathrm{t}$ \\
\hline 25 & Teat & 86 & & $\mathrm{t}$ & $\mathrm{i}:$ & $\mathrm{t}$ \\
\hline 26 & Coup & 79 & & $\mathrm{k}$ & u: & none \\
\hline 27 & Peak & & 67 & $\mathrm{p}$ & $\mathrm{i}:$ & $\mathrm{k}$ \\
\hline 28 & Put & & 78 & $\mathrm{p}$ & $\mathrm{u}$ & $\mathrm{t}$ \\
\hline 29 & Too & 49 & & $\mathrm{t}$ & $\mathrm{u}:$ & None \\
\hline 30 & Keen & 105 & & $\mathrm{k}$ & i: & $\mathrm{N}$ \\
\hline 31 & Tag & 51 & & $\mathrm{t}$ & $æ$ & $\mathrm{~g}$ \\
\hline 32 & Keep & 66 & & $\mathrm{k}$ & i: & $\mathrm{p}$ \\
\hline 33 & & 81 & & $\mathrm{p}$ & $\mathrm{i}:$ & $\mathrm{p}$ \\
\hline 34 & Teat & 55 & & $\mathrm{t}$ & i: & $\mathrm{T}$ \\
\hline 35 & Key & 133 & & $\mathrm{k}$ & $\mathrm{i}:$ & None \\
\hline 36 & Pick & 21 & & $\mathrm{p}$ & $\mathrm{i}$ & $\mathrm{k}$ \\
\hline 37 & Tea & 53 & & $\mathrm{t}$ & $\mathrm{i}:$ & None \\
\hline 38 & Kid & 59 & & $\mathrm{k}$ & $\mathrm{i}$ & $\mathrm{d}$ \\
\hline 39 & Pee & 74 & & $\mathrm{p}$ & i: & None \\
\hline 40 & Tag & 36 & & $\mathrm{t}$ & $æ$ & $\mathrm{~g}$ \\
\hline 41 & Cook & 58 & & $\mathrm{k}$ & $\mathrm{u}$ & $\mathrm{k}$ \\
\hline 42 & Coup & 48 & & $\mathrm{k}$ & $\mathrm{u}:$ & None \\
\hline 43 & Too & 28 & & $\mathrm{t}$ & $\mathrm{u}:$ & None \\
\hline 44 & Pea & 69 & & $\mathrm{p}$ & i: & None \\
\hline 45 & Put & & 65 & $\mathrm{p}$ & $\mathrm{u}$ & $\mathrm{t}$ \\
\hline 46 & Tip & 49 & & $\mathrm{t}$ & $\mathrm{i}$ & $\mathrm{p}$ \\
\hline 47 & $\mathrm{Ka}$ & 51 & & $\mathrm{k}$ & $\mathrm{a}$ & None \\
\hline 48 & Pool & 79 & & $\mathrm{p}$ & $\mathrm{u}:$ & 1 \\
\hline 49 & $\mathrm{Ta}$ & 25 & & $\mathrm{t}$ & $\mathrm{a}$ & None \\
\hline 50 & Pool & 68 & & $\mathrm{p}$ & u: & 1 \\
\hline
\end{tabular}

\section{$\boldsymbol{B}$}

Ramzi's production of Voiced stops in following words

$\begin{array}{cccccc}\text { No. } & \text { Word } & \text { VOT } & \text { Sound } & \text { F.V } & \text { C.F.V } \\ & \text { Positive } & \text { Negative } & & & \\ 1 & \text { Back } & 91 & \mathrm{~b} & \mathfrak{x} & \mathrm{k} \\ 2 & \text { Deep } & 98 & \mathrm{~d} & \mathrm{i}: & \mathrm{p} \\ 3 & \text { Good } & 95 & \mathrm{~g} & \mathrm{u} & \mathrm{d} \\ 4 & \text { Bee } & 112 & \mathrm{~b} & \mathrm{i}: & \text { none } \\ 5 & \text { Dap } & 1022 & \mathrm{~d} & \mathfrak{x} & \mathrm{p} \\ 6 & \text { Gad } & 65 & \mathrm{~g} & \mathfrak{x} & \mathrm{d}\end{array}$




\begin{tabular}{|c|c|c|c|c|c|c|}
\hline 7 & Boo & & 51 & $\mathrm{~b}$ & $\mathrm{u}$ : & none \\
\hline 8 & Doom & & 98 & $\mathrm{~d}$ & $\mathrm{u}:$ & $\mathrm{m}$ \\
\hline 9 & Gap & & 102 & $\mathrm{~g}$ & $æ$ & $\mathrm{p}$ \\
\hline 10 & Beat & & 76 & $\mathrm{~b}$ & i: & $\mathrm{t}$ \\
\hline 11 & Dim & & 126 & $\mathrm{~d}$ & $\mathrm{i}$ & $\mathrm{m}$ \\
\hline 12 & Bead & & 83 & $\mathrm{~b}$ & i: & $\mathrm{d}$ \\
\hline 13 & Deed & & 126 & $\mathrm{~d}$ & $\mathrm{~d}$ & $\mathrm{i}:$ \\
\hline 14 & Bid & & 55 & b & $\mathrm{i}$ & d \\
\hline 15 & Did & & 123 & $\mathrm{~d}$ & $\mathrm{i}$ & $\mathrm{d}$ \\
\hline 16 & Ghee & & 81 & $\mathrm{~g}$ & i: & none \\
\hline 17 & $\mathrm{Bad}$ & & 94 & $\mathrm{~b}$ & $æ$ & $\mathrm{~d}$ \\
\hline 18 & $\mathrm{D}$ & & 128 & d & $\mathrm{i}:$ & none \\
\hline 19 & Goof & & 85 & $\mathrm{~g}$ & $\mathrm{u}:$ & $\mathrm{f}$ \\
\hline 20 & Bat & 10 & & b & $æ$ & $\mathrm{t}$ \\
\hline 21 & Dig & & 173 & $\mathrm{~d}$ & $\mathrm{i}$ & $\mathrm{g}$ \\
\hline 22 & Gall & & 100 & g & $æ$ & 1 \\
\hline 23 & Deep & & 65 & $\mathrm{~d}$ & i: & $\mathrm{p}$ \\
\hline 24 & $\mathrm{Gad}$ & & 86 & $\mathrm{~g}$ & $æ$ & $d$ \\
\hline 25 & $\mathrm{Bab}$ & & 81 & $\mathrm{~b}$ & $æ$ & $\mathrm{~b}$ \\
\hline 26 & Do & & 72 & $\mathrm{~d}$ & $\mathrm{u}:$ & none \\
\hline 27 & $\mathrm{Ga}$ & & 89 & g & $\mathrm{a}$ & none \\
\hline 28 & Beep & & 73 & $\mathrm{~b}$ & $\mathrm{i}:$ & $\mathrm{p}$ \\
\hline 29 & Dap & & 43 & $\mathrm{~d}$ & $æ$ & $\mathrm{p}$ \\
\hline 30 & Boot & & 88 & $\mathrm{~b}$ & $\mathrm{u}$ : & $\mathrm{t}$ \\
\hline 31 & Deep & & 79 & $\mathrm{~d}$ & i: & $\mathrm{p}$ \\
\hline 32 & Goods & & 99 & $\mathrm{~g}$ & $\mathrm{u}$ & $\mathrm{dz}$ \\
\hline 33 & Book & & 110 & $\mathrm{~b}$ & $\mathrm{u}$ & $\mathrm{k}$ \\
\hline 34 & Dupe & & 58 & $\mathrm{~d}$ & $\mathrm{u}:$ & $\mathrm{p}$ \\
\hline 35 & Goose & & 99 & $\mathrm{~g}$ & $\mathrm{u}:$ & $\mathrm{s}$ \\
\hline 36 & Bee & & 68 & b & i: & none \\
\hline 37 & Dip & & 102 & $\mathrm{~d}$ & $\mathrm{i}$ & $\mathrm{p}$ \\
\hline 38 & Give & & 85 & $\mathrm{~g}$ & $\mathrm{i}$ & $\mathrm{v}$ \\
\hline 39 & Geek & & 68 & $\mathrm{~g}$ & i: & $\mathrm{k}$ \\
\hline 40 & $\mathrm{Da}$ & & 103 & d & $\mathrm{a}$ & none \\
\hline 41 & Been & & 58 & b & i: & $\mathrm{n}$ \\
\hline 42 & Bag & & 62 & $\mathrm{~b}$ & $\mathfrak{x}$ & g \\
\hline 43 & Dip & & 137 & $\mathrm{~d}$ & $\mathrm{i}$ & $\mathrm{p}$ \\
\hline 44 & Geese & & 109 & $\mathrm{~g}$ & $\mathrm{i}:$ & $\mathrm{s}$ \\
\hline 45 & Baa & & 81 & $\mathrm{~b}$ & aa & none \\
\hline 46 & Dude & & 89 & d & $\mathrm{u}:$ & $\mathrm{d}$ \\
\hline 47 & Goo & & 65 & $\mathrm{~g}$ & u: & \\
\hline 48 & Beak & & 59 & $\mathrm{~b}$ & i: & $\mathrm{k}$ \\
\hline
\end{tabular}


C

Fadhl's voiceless stops

Word sound VOT F.V F.C word

Fadhl Voiced stops

\begin{tabular}{|c|c|c|c|c|c|c|c|c|c|c|}
\hline & Word & sound & VOT & F.V & F.C & word & sound & VOT & F.V & F.C \\
\hline 1 & $\mathrm{P}$ & $\mathrm{p}$ & 26 & I & None & Back & b & -93 & $æ$ & $\mathrm{~K}$ \\
\hline 2 & Two & $\mathrm{t}$ & 51 & $\mathrm{u}:$ & none & Deep & $\mathrm{d}$ & -118 & I: & $\mathrm{P}$ \\
\hline 3 & Key & $\mathrm{k}$ & 72 & I: & none & Good & g & -131 & $\mathrm{u}$ & $\mathrm{D}$ \\
\hline 4 & Peak & $\mathrm{p}$ & 34 & I: & $\mathrm{k}$ & Bee & b & -92 & I: & none \\
\hline 5 & Tick & $\mathrm{t}$ & 31 & I & $\mathrm{k}$ & Dap & $\mathrm{d}$ & -130 & $æ$ & $\mathrm{P}$ \\
\hline 6 & Can & $\mathrm{k}$ & 33 & $Æ$ & $\mathrm{n}$ & Gad & g & -111 & $æ$ & $\mathrm{D}$ \\
\hline 7 & Peat & $\mathrm{p}$ & 77 & I: & $\mathrm{t}$ & Boo & b & -86 & u: & none \\
\hline 8 & Teak & $\mathrm{t}$ & 59 & I: & $\mathrm{k}$ & Doom & $d$ & -123 & u: & $\mathrm{m}$ \\
\hline 9 & $\mathrm{Cad}$ & $\mathrm{k}$ & 31 & $æ$ & $d$ & Gab & $\mathrm{g}$ & -122 & $æ$ & b \\
\hline 10 & $\mathrm{~Pa}$ & $\mathrm{p}$ & 50 & $\mathrm{a}$ & none & Beat & b & -107 & i: & $\mathrm{t}$ \\
\hline 11 & Took & $\mathrm{t}$ & 26 & $\mathrm{u}$ & $\mathrm{k}$ & Bead & $\mathrm{b}$ & -131 & i: & $d$ \\
\hline 12 & Cap & $\mathrm{k}$ & 43 & $æ$ & $\mathrm{p}$ & Bid & b & -81 & $\mathrm{i}$ & $d$ \\
\hline 13 & $\mathrm{Pad}$ & $\mathrm{p}$ & 41 & $æ$ & d & Did & $d$ & -97 & $\mathrm{i}$ & $d$ \\
\hline 14 & Teat & $\mathrm{t}$ & 48 & I: & $\mathrm{t}$ & Ghee & $\mathrm{g}$ & -118 & i: & none \\
\hline 15 & Cap & $\mathrm{k}$ & 25 & $æ$ & b & $\mathrm{Bad}$ & b & -55 & $æ$ & $d$ \\
\hline 16 & Pack & $\mathrm{p}$ & 48 & $æ$ & $\mathrm{k}$ & $\mathrm{D}$ (Letter) & d & -124 & i: & none \\
\hline 17 & Tag & $\mathrm{t}$ & 28 & $æ$ & $\mathrm{~g}$ & Goof & $\mathrm{g}$ & -148 & u: & $\mathrm{f}$ \\
\hline 18 & Cat & $\mathrm{k}$ & 34 & $æ$ & $\mathrm{t}$ & Bat & $\mathrm{b}$ & -75 & $æ$ & $\mathrm{t}$ \\
\hline 19 & $\mathrm{~Pa}$ & $\mathrm{p}$ & 30 & $\mathrm{a}$ & none & Dig & d & -72 & $\mathrm{i}$ & $\mathrm{g}$ \\
\hline 20 & $\mathrm{Tad}$ & $\mathrm{t}$ & 35 & $æ$ & $\mathrm{~d}$ & Gall & $\mathrm{g}$ & -87 & $æ$ & 1 \\
\hline 21 & Key & $\mathrm{k}$ & 60 & i: & none & Beak & $\mathrm{b}$ & -105 & i: & $\mathrm{k}$ \\
\hline 22 & Pat & $\mathrm{p}$ & 47 & $æ$ & $\mathrm{t}$ & Deep & d & -81 & I: & $\mathrm{p}$ \\
\hline 23 & Tat & $\mathrm{t}$ & 19 & $æ$ & $\mathrm{t}$ & Gad & $\mathrm{g}$ & -81 & $æ$ & $\mathrm{~d}$ \\
\hline 24 & Could & $\mathrm{k}$ & 41 & $\mathrm{u}$ & $\mathrm{d}$ & Bap & $\mathrm{b}$ & -58 & $æ$ & $\mathrm{p}$ \\
\hline 25 & Pit & $\mathrm{p}$ & 32 & $\mathrm{i}$ & $\mathrm{t}$ & Do & $\mathrm{d}$ & -66 & $\mathrm{u}:$ & none \\
\hline 26 & Teat & $\mathrm{t}$ & 29 & i: & $\mathrm{t}$ & $\mathrm{Ga}$ & $\mathrm{g}$ & -88 & $\mathrm{a}$ & none \\
\hline 27 & Coup & $\mathrm{k}$ & 22 & $\mathrm{u}:$ & none & Beep & $\mathrm{b}$ & -72 & I: & $\mathrm{p}$ \\
\hline 28 & Put & $\mathrm{p}$ & 38 & $\mathrm{u}$ & $\mathrm{t}$ & Dap & $\mathrm{d}$ & -83 & $æ$ & $\mathrm{p}$ \\
\hline 29 & Too & $\mathrm{t}$ & 38 & $\mathrm{u}$ & none & Boot & $\mathrm{b}$ & -94 & u: & $\mathrm{t}$ \\
\hline 30 & Keen & $\mathrm{k}$ & 70 & i: & $\mathrm{n}$ & Deep & d & -78 & i: & $\mathrm{p}$ \\
\hline 31 & Pool & $\mathrm{p}$ & 83 & u: & 1 & Goods & $\mathrm{g}$ & -143 & u: & $\mathrm{dz}$ \\
\hline
\end{tabular}




$\begin{array}{lcccccccccc}32 & \text { Tag } & \mathrm{t} & 24 & \mathfrak{2} & \mathrm{g} & \text { Book } & \mathrm{b} & -76 & \mathrm{u} & \mathrm{k} \\ 33 & \text { Keep } & \mathrm{k} & 50 & \mathrm{i}: & \mathrm{p} & \text { Dude } & \mathrm{d} & -86 & \mathrm{u}: & \mathrm{d} \\ 34 & \text { Peep } & \mathrm{p} & 57 & \mathrm{i}: & \mathrm{p} & \text { Goose } & \mathrm{g} & -105 & \mathrm{u}: & \mathrm{s} \\ 35 & \text { Teat } & \mathrm{t} & 24 & \mathrm{i}: & \mathrm{T} & \text { Dip } & \mathrm{d} & -73 & \mathrm{i} & \mathrm{p} \\ 36 & \text { Key } & \mathrm{k} & 64 & \mathrm{i}: & \text { none } & \text { Give } & \mathrm{g} & -101 & \mathrm{i} & \mathrm{v} \\ 37 & \text { Pick } & \mathrm{p} & 36 & \mathrm{i} & \mathrm{k} & \text { Geek } & \mathrm{g} & -99 & \mathrm{i}: & \mathrm{k} \\ 38 & \text { Tea } & \mathrm{t} & 38 & \mathrm{I}: & \text { none } & \text { Da } & \mathrm{d} & -65 & \mathrm{a} & \text { none } \\ 39 & \text { Kid } & \mathrm{k} & 32 & \mathrm{i} & \mathrm{d} & \text { Been } & \mathrm{b} & -95 & \mathrm{i}: & \mathrm{n} \\ 40 & \text { Pee } & \mathrm{p} & 47 & \mathrm{i}: & \text { none } & \text { Bag } & \mathrm{b} & -13 & \mathfrak{x} & \mathrm{g} \\ 41 & \text { Tag } & \mathrm{t} & 28 & \mathfrak{x} & \mathrm{g} & \text { Dip } & \mathrm{d} & -68 & \mathrm{i} & \mathrm{p} \\ 42 & \text { Cook } & \mathrm{k} & 31 & \mathrm{u} & \mathrm{k} & \text { Geese } & \mathrm{g} & -70 & \mathrm{I}: & \mathrm{s} \\ 43 & \text { Coup } & \mathrm{k} & 91 & \mathrm{i}: & \text { none } & \text { Ba } & \mathrm{b} & -74 & \mathrm{a} & \\ 44 & \text { Too } & \mathrm{t} & 337 & \mathrm{u} & \text { none } & \text { Dude } & \mathrm{d} & -60 & \mathrm{u}: & \mathrm{d} \\ 45 & \text { Pea } & \mathrm{p} & 46 & \mathrm{i}: & \text { none } & \text { Goo } & \mathrm{g} & -102 & \mathrm{u}: & \\ 46 & \text { Put } & \mathrm{p} & 57 & \mathrm{u} & \mathrm{t} & \text { Big } & \mathrm{b} & -84 & \mathrm{i} & \mathrm{g} \\ 47 & \text { Tip } & \mathrm{t} & 26 & \mathrm{i} & \mathrm{p} & \text { Dad } & \mathrm{d} & -50 & \mathfrak{x} & \mathrm{d} \\ 48 & \text { Ka } & \mathrm{k} & 28 & \mathrm{a} & \text { none } & \text { Gag } & \mathrm{g} & -99 & \mathfrak{x} & \mathrm{g} \\ 49 & \text { Poo } & \mathrm{p} & 68 & \mathrm{U}: & \text { none } & \text { Get } & \mathrm{g} & -93 & \mathrm{e} & \mathrm{t} \\ 50 & \text { Ta } & \mathrm{t} & 19 & \mathrm{a} & \text { none } & & & & & \\ 51 & \text { Kaa } & \mathrm{k} & 37 & \mathrm{aa} & \text { none } & & & & & \\ 52 & \text { Cook } & \mathrm{k} & 22 & \mathrm{u} & \mathrm{k} & & & & & \\ 53 & \text { Peak } & \mathrm{p} & 60 & \mathrm{I}: & \mathrm{k} & & & & & \\ 54 & \text { Tat } & \mathrm{t} & 20 & \mathfrak{x} & \mathrm{t} & & & & & \\ & & & & & & & & & & \end{array}$

D

Mean, Median, Range, Mode, Largest Value, Smallest Value and Standard Deviation (SD) for the two subjects Fadhl and Ramzi

\begin{tabular}{|c|c|c|c|c|c|c|c|}
\hline \multicolumn{2}{|c|}{ Subjects } & $/ \mathrm{p} /$ & $/ \mathrm{t} /$ & $/ \mathbf{k} /$ & /b/ & $/ \mathrm{d} /$ & /g/ \\
\hline \multirow[t]{2}{*}{ Mean } & $\mathrm{F}$ & 48.72 & 32.22 & 43.66 & -81.82 & -79.5 & -106.12 \\
\hline & $\mathrm{R}$ & 31.11 & 50.7 & 70.18 & -72.47 & -101.29 & -87.71 \\
\hline \multirow[t]{2}{*}{ Median } & $\mathrm{F}$ & 47 & 28.5 & 35.5 & -84 & -79.5 & -101.5 \\
\hline & $\mathrm{R}$ & 57 & 51 & 62.5 & -76 & -102 & -87.5 \\
\hline \multirow[t]{2}{*}{ Range } & $\mathrm{F}$ & 57 & 40 & 69 & -118 & -80 & -78 \\
\hline & $\mathrm{R}$ & 159 & 61 & 96 & -122 & -130 & -44 \\
\hline
\end{tabular}


Mode $\quad F \quad(47,57) X 2 \quad(26,28,19,38,24) X 2 \quad(22,31) \times 2 \quad$ Once all Once all $\quad(-99) \times 2$

$\mathrm{R} \quad(78,49,-\quad(49) \times 2 \quad(37, \quad(-81) \times 2 \quad(-98,-\quad(-65,-$

78) $\times 2 \quad 90) \times 2 \quad 102,-\quad 85,-$

$\begin{array}{cccccccc}\text { Largest } & \text { F } & 83 & 69 & 91 & -131 & -130 & -148 \\ & \text { R } & 81 & 86 & 133 & 10 & -173 & -109 \\ \text { Smallest } & \text { F } & 26 & 19 & 22 & -13 & -50 & -70 \\ & \text { R } & -78 & 25 & 37 & -112 & -43 & -65 \\ \text { SD } & \text { F } & 15.5 & 10.99 & 19.3 & -24.76 & -24.3 & -21.06 \\ & \text { R } & 59.05 & 16.14 & 26.02 & -26.98 & -31.57 & -13.62 \\ \text { Count } & \text { F } & 18 & 18 & 18 & 17 & 16 & 16 \\ & \text { R } & 17 & 17 & 16 & 17 & 17 & 14\end{array}$

Note: The 'F' and 'R' in the appendix stands for Fadhl and Ramzi.

$\boldsymbol{E}$

VOT values for repeated words in different recording sessions

\begin{tabular}{|c|c|c|c|c|c|c|c|}
\hline \multicolumn{4}{|c|}{ Ramzi } & \multicolumn{4}{|c|}{ Fadhl } \\
\hline & & & & No. & Session & Word & VOT \\
\hline No. & Session & Word & VOT & 1 & 1 & coup & 91 \\
\hline \multirow[t]{2}{*}{1} & 1 & Tea & 63 & & 2 & coup & 22 \\
\hline & 2 & Tea & 53 & 2 & 1 & peak & 60 \\
\hline \multirow[t]{3}{*}{2} & 1 & Tag & 66 & & 2 & peak & 34 \\
\hline & 2 & Tag & 51 & 3 & 1 & good & -143 \\
\hline & 3 & Tag & 36 & & 2 & good & -131 \\
\hline \multirow[t]{2}{*}{3} & 1 & Teat & 86 & 4 & 1 & ka & 37 \\
\hline & 2 & Teat & 55 & & 2 & ka & 28 \\
\hline \multirow[t]{2}{*}{4} & 1 & Coup & 79 & 5 & 1 & cap & 25 \\
\hline & 2 & Coup & 48 & & 2 & cap & 43 \\
\hline \multirow[t]{2}{*}{5} & 1 & $\mathrm{Gad}$ & 65 & 6 & 1 & pa & 30 \\
\hline & 2 & Gad & 86 & & 2 & $\mathrm{~Pa}$ & 50 \\
\hline
\end{tabular}




\begin{tabular}{|c|c|c|c|c|c|c|c|}
\hline \multirow[t]{2}{*}{6} & 1 & Put & -78 & 7 & 1 & put & 57 \\
\hline & 2 & Put & -65 & & 2 & put & 38 \\
\hline \multirow[t]{2}{*}{7} & 1 & Pool & 79 & 8 & 1 & Tat & 19 \\
\hline & 2 & Pool & 68 & & 2 & Tat & 20 \\
\hline \multirow[t]{2}{*}{8} & 1 & Peak & 78 & 9 & 1 & Dip & -68 \\
\hline & 2 & Peak & -67 & & 2 & Dip & -73 \\
\hline \multirow[t]{2}{*}{9} & 1 & Bee & -68 & 10 & 1 & teat & 24 \\
\hline & 2 & Bee & -112 & & 2 & Teat & 48 \\
\hline \multirow[t]{4}{*}{10} & 1 & Dip & -102 & & 3 & Teat & 48 \\
\hline & 2 & Dip & -137 & 11 & 1 & Deep & -78 \\
\hline & & & & & 2 & Deep & -81 \\
\hline & & & & & 3 & Deep & -118 \\
\hline
\end{tabular}

VOT values for repeated words of both subjects, Ramzi and Fadhl 